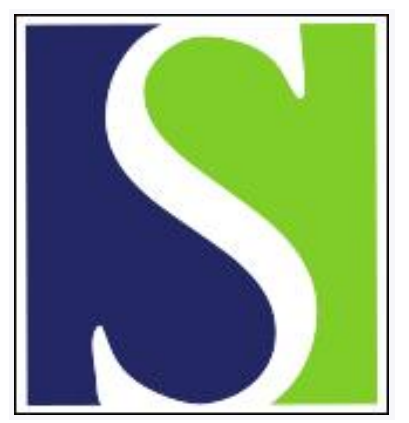

Scand J Work Environ Health 2009;35(1):37-47

https://doi.org/10.5271/sjweh.1301

Published online: 19 Feb 2009, Issue date: 00 Jan 2009

Development trajectories of Finnish managers' work ability over a 10-year follow-up period

by Feldt T, Hyvönen K, Mäkikangas A, Kinnunen U, Kokko K

Affiliation: University of Jyväskylä, Department of Psychology, PO Box 35, FI-40014 University of Jyväskylä, Jyväskylä, Finland. taru.feldt@psyka.jyu.fi

Refers to the following texts of the Journal: 1997;23 suppl 1:27-35

2003;29(2):159-165 2007;33(5):351-357 2006;32(1):75-84

1995;21(2):143-150 1997;23 suppl 1:49-57 1997;23 suppl 1:7-11 1997;23 suppl 1:66-71

The following articles refer to this text: $2009 ; 35(1): 1-5$;

2010;36(5):404-412; 2011;37(6):455-463; 2011;37(6):451-453;

2014;40(4):380-389; 2020;46(2):168-176

Key terms: Finland; follow-up; job control; manager; organizational climate; organizational commitment; trajectory analysis; work ability; work ability index; work involvement

This article in PubMed: www.ncbi.nlm.nih.gov/pubmed/19225701

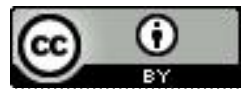




\title{
Development trajectories of Finnish managers' work ability over a 10-year follow-up period
}

\author{
by Taru Feldt, PhD, ${ }^{1}$ Katriina Hyvönen, MSc, ${ }^{1}$ Anne Mäkikangas, PhD, ${ }^{1}$ Ulla Kinnunen, PhD, ${ }^{2}$ Katja Kokko, \\ $P h D^{1}$
}

\begin{abstract}
Feldt T, Hyvönen K, Mäkikangas A, Kinnunen U, Kokko K. Development trajectories of Finnish managers' work ability over a 10-year follow-up period. Scand J Work Environ Health. 2009;35(1):37-47.
\end{abstract}

Objectives The study investigated the development trajectories of managers' work ability over a 10-year period. In addition, baseline factors affecting the development course were sought from the managers' background variables, work resources, and attitudes. Differences in retirement age in the detected trajectory groups were also examined.

Methods Questionnaire data were collected from Finnish managers (N=1033) in 1996, 1999, and 2006. In 1996, the mean age of the participants was 44 (range 20-65) years, and 28.5\%, 35.5\%, and 36\% of the participants were in upper, middle, and lower management, respectively.

Results The analysis identified the following five trajectories over the follow-up period: (i) work ability consistently excellent ( $\mathrm{N}=662)$, (ii) work ability good but declining $(\mathrm{N}=252)$, (iii) work ability declined from good to poor $(\mathrm{N}=54)$, (iv) work ability improved from moderate to good $(\mathrm{N}=46)$, and (v) work ability consistently poor $(\mathrm{N}=19)$. In the first group, the participants were more likely to be younger and to work in upper management, as compared with the other groups. They also gave their job control, organizational climate, and organizational commitment the highest rating. The mean retirement age was the highest (61.3 years) in the two most favorable work ability groups (1 and 2) and the lowest (55.4 years) in the group "work ability consistently poor".

Conclusions Aging managers and lower-level managers are at risk of having their work ability develop in an unfavorable direction. Therefore, more attention should be given to psychosocial work conditions in organizations in order to prevent poor work ability.

Key terms job control; organizational climate; organizational commitment; trajectory analysis; work involvement; work ability index.

The age structure of the labor force in European countries is becoming increasingly unfavorable, a trend expected to continue over the next couple of decades. The exit of aging people from the labor market, coinciding with decreasing sizes of younger age groups, is considered to be one of the most important social and economic challenges in Europe over the few next decades (1). Declining health and work ability have been flagged as the main reasons for retirement by aging employees (2). However, there are only a few longitudinal studies on work ability and its development. The aim of our study was to shed further light on this issue by identifying the development trajectories of work ability within an extensive 10-year follow-up study originally consisting of over 1000 Finnish managers. To our knowledge, there is no previous research available regarding such person- oriented trajectories of work ability among working-age employees. With the use of a person-oriented approach, it is possible to gain a more in-depth understanding of the direction in which the work ability groups (eg, including risk groups) of workers with different levels of work ability develop over time, as well as determine the baseline factors that affect this development. This knowledge is useful in sustaining employees' work ability through occupational health care and organizational development.

The work ability concept is based on the assumption that work ability is determined by persons' perceptions of the demands on them at work and of their ability to cope with these demands. Thus, although work ability is assessed as an individual ability, the work itself represents an essential element of it, as work ability describes the balance between work demands and a person's

1 Department of Psychology, University of Jyväskylä, University of Jyväskylä, Jyväskylä, Finland.

2 Department of Psychology, University of Tampere, Tampere, Finland.

Reprint requests to: Dr T Feldt, University of Jyväskylä, Department of Psychology, PO Box 35, FI-40014 University of Jyväskylä, Jyväskylä, Finland. [E-mail: taru.feldt@ psyka.jyu.fi] 
functional capacity (health, competence, values) (3-6). A decline in work ability could, therefore, be a consequence of deficits in a person's functional capacity or excessive work demands. Ideally, the assessment of work ability should be based on both objective observations (eg, medical examinations) and on employees' subjective estimations of their resources in relation to work demands (6). Since the use of objective estimations would be too laborious and expensive for many large-scale investigations in occupational health care and epidemiologic research, the self-rated work ability index was developed at the onset of follow-up studies conducted at the Finnish Institute of Occupational Health in the early 1980 s (5-10).

Our present study of the change in work ability over time is based on the utilization of the work ability index. The work ability index is a questionnaire-based method for use in occupational health care and research consisting of seven indicators that help answer the question of how well or healthy employees are currently and in the near future and, in addition, how able they are to do their work with respect to their work demands, health, and mental resources (6). In addition to the subjective estimations of work ability in relation to work demands, the work ability index also includes the dimensions of the determinants (ie, health) and outcomes (ie, consequences of health in terms of sick leave and functional limitations) of work ability. Thus far, the questionnaire used for the work ability index has been translated into 26 languages and is used in several countries $(11,12)$. Essentially, the index is a diagnostic tool designed to support employees. On the basis of the information gained from the work ability index, employees who require support from occupational health care and who need improvements in work conditions as means of preventing a premature decrease in work ability can be identified $(13,14)$.

The value of the work ability index as a measure is also evident in empirical studies. In prospective studies, it has been found to predict sick leave $(15,16)$, as well as work disability (17), early retirement $(17,18)$, and mortality $(9,17)$. In investigating changes in work ability, the research performed thus far has been based predominantly on a variable-centered approach. As a result, changes in work ability have been investigated on a group level as changes in the mean scores of the work ability index. In this respect, previous research has shown that mean scores of the index are lower for older age groups of employees $(5,18-22)$ and for employees with physically demanding work $(5,21)$. However, by analyzing the mean scores in predefined groups, information is gained only regarding the common trends, and, for example, there is a risk that any atypical development paths of work ability remain undetected.

In our present study, we approached the changes in managers' work ability from a person-oriented perspective (23-27), and our aim was to identify the persons whose work ability and its changes between 1996 and 2006 were as similar as possible. The persons identified as closely resembling each other with respect to work ability and its change over time were considered to belong to one latent work ability group, which was called a development trajectory. Different development trajectories are investigated by means of a trajectory analysis (28-29), which is a reasonably novel modeling method for finding so-called latent groups in longitudinal research (30). With the use of this modeling method, it is possible to identify different sizes of latent groups on the basis of both the level and development course of the phenomenon under study. The investigation of development trajectories can identify employee groups at risk. In addition, the baseline factors shown to be related to a decline in work ability can be determined.

The target group of this study, that is, managers, represents a salient group in worklife. They hold key positions in the organizational hierarchy due to their role in setting the direction for their subordinates and in communicating across organizational levels. Their roles and, in particular, their leadership styles are also considered essential factors affecting their employees' work ability in the organization $(3-5,19)$. However, managers' own work ability has been studied only rarely thus far, and, consequently, our present study was designed to fill this void.

To summarize, the main objectives of this study were threefold. First, we investigated the types of development trajectories found for the work ability of managers who participated in a 10-year follow-up study. Due to the exploratory nature of this objective (and the methodological approach as well), no firm hypothesis could be formed concerning the development trajectories of the manager's work ability (ie, their level, direction, or number). However, when the nature of managerial work (eg, low physical demands, high job control) is considered (31), it is reasonable to expect that the development of work ability is favorable for most managers. Therefore, we expected to find trajectories with excellent or at least good work ability throughout the entire 10-year follow-up period. In addition, we assumed that, with advancing age, a trajectory of declining work ability would also emerge.

Second, we investigated the baseline factors that could distinguish between the different trajectories of work ability. These factors included managers' background characteristics (age, managerial level), perceived work resources (supportive organizational climate, job control), and work attitudes (job involvement, organizational commitment). After an examination of the literature on work ability and occupational health, we hypothesized that younger age and higher managerial level would predict positive work ability trajectories (5, 
18-22, 31-33). We further hypothesized that high levels of work resources would serve as favorable factors for the development of work ability $(15,21,22,32,34-38)$, as would high job involvement and organizational commitment (39).

Third, we investigated the proportions of retirees in the detected trajectories at the last measurement (in 2006) and, especially, whether the age of retirement differed between the persons in the obtained trajectories. We hypothesized, in line with previous observations (17, 18), that the age of retirement would be lower for the retirees with unfavorable work ability trajectories.

\section{Study population and methods}

The study was a part of a wider research project, FINNMA-10, which focused on managerial work and on the changes in work and occupational well-being over a period of 10 years, with three measurement times $(1996,1999,2006)(40,41)$. The study sample was collected in 1996 (selection being directed towards employees with managerial titles) from the member registers of two national labor unions, the Union of Technical Employees (currently known as the Union of Salaried Employees) and the Union of Professional Engineering. The questionnaire was sent to the home addresses of 1000 members of the Union of Professional Engineering and 1000 members of the Union of Technical Employees. Of these, 1035 persons completed and returned the questionnaire. They accounted for $64 \%$ of the sent questionnaires after those $(\mathrm{N}=389)$ who were not in a managerial position, were retired, or had been unemployed or laid off for more than 3 months were omitted. [They had been asked to return a blank questionnaire.]

At the baseline of the study in 1996, the participants were 20-65 (mean 44.0) years of age, and 93\% ( $\mathrm{N}=960$ ) were male. Those in upper management comprised $28.5 \%$ of the respondents, whereas $35.5 \%$ were in middle management and 36\% were in lower management. Most of the participants had training in technical professions, that is, engineering or higher university degrees $(52.7 \%)$, technicians (28.9\%), or other technical qualifications (14.7\%). The remaining participants had training in fields that were not technical $(0.4 \%)$ or had no professional training $(3.3 \%)$. Nearly all of the participants $(99.2 \%)$ were employed (98\% with a permanent contract and 2\% with a temporary contract). In 1996 only $0.8 \%$ of the participants were unemployed or had been laid off (under 3 months). The participants represented various occupational branches, among which the larger groups were the metal industry (26\%), chemical industry (9\%), building industry (7\%), paper industry
(7\%), food industry (6\%), electric power industry $(6 \%)$, mechanical forest or woodworking industry $(5 \%)$, and consultancy $(5 \%)$.

A total of 635 managers responded to the follow-up questionnaire sent to the original respondents 3 years later, in 1999. In 1999, $70 \%$ of the participants had responded after the 118 persons who were no longer in managerial positions or had retired were omitted. [The questionnaire had been directed to managers only.] The participants were 27-66 (mean 46.8) years of age, and $95 \%$ were male. Of the respondent managers, $31.6 \%$, $35.8 \%$, and $32.6 \%$ belonged to upper management, middle management, and lower management, respectively.

In 2006, the study was sent to all of those who had responded in 1996, independent of their current employment status. The questionnaire could be mailed to 998 people ( 25 had died, 10 had their address withheld, and 2 could not be identified due to missing participant identification). Altogether 785 people responded (78\%). In 2006, the participants were 30-75 (mean 54.6) years of age, and $93 \%$ were male. Of the respondents, $57 \%$ $(\mathrm{N}=451)$ were still in management, and $17 \%(\mathrm{~N}=131)$ were working in other roles (eg, as a consultant). Of the managers, 53\% represented upper management, $26 \%$ were in middle management, and $21 \%$ were in lower management. Among the other participants, 20\% $(\mathrm{N}=155)$ were retired, $5 \%(\mathrm{~N}=42)$ were unemployed, and $1 \%(\mathrm{~N}=8)$ did something else (eg, studying).

Of the total sample, 51\% (N=529) participated in the study at each measurement point, $35 \%(\mathrm{~N}=362)$ participated at two measurement points (either 1996 and 1999 or 1996 and 2006), and 14\% (N=144) participated only in 1996.

\section{Measures}

Work ability was measured with the questionnaire that determined the work ability index $(13,14)$. The index is comprised of the following seven dimensions: (i) subjective estimation of current work ability compared with the lifetime best, (ii) perceived work ability in relation to both the physical and mental demands of work, (iii) the number of diseases diagnosed by a physician, (iv) a subjective estimation of work impairment due to disease, (v) absences due to sickness during the past year, (vi) own prognosis of work ability after 2 years, and (vii) psychological resources. The simple sum score (which forms the work ability index) rates each person on a scale of 7 (very poor work ability) to 49 (excellent work ability). This score has also been classified into the following four categories of work ability: (i) poor (values 7-27), (ii) moderate (values 28-36), (iii) good (values 37-43), and (iv) excellent (values 44-49). However, in our study, the continuous sum score was used. The work ability index was calculated only for 
the participants who were employed at the measurement time in question because the measure incorporates questions regarding the participants' current employment.

\section{Work resources at the baseline of the study (in 1996)}

A supportive organizational climate was assessed with four items concerning the general social climate in the organization and the support of colleagues (eg, "Our workplace is dominated by an atmosphere of openness and solidarity." "We have free-flowing communication in our workplace.") $(32,42)$. The participants were asked to respond to each item on a 5-point scale ( $1=$ totally disagree, 5 = totally agree). This scale has been reported to have good construct validity in previous phases of the study (42).

Job control was measured via four items $(32,42)$ [ie, to what extent the current job offered (i) independence, (ii) responsibility, (iii) opportunities to use one's own skills, and (iv) control over one's own work]. The responses were given on a 5-point scale $(1=$ not at all, 5 = very much). Evidence for good construct validity has been reported previously for this scale also (42).

\section{Work attitudes at the baseline of the study (in 1996)}

Job involvement was evaluated with the use of four items $(43,44)$ (eg, "The most important things that happen to me involve my present job." "I am very involved personally in my job."). The response scale ranged between 1 (totally disagree) and 4 (totally agree). Thereby a high score of the formed sum variable indicated high job involvement.

Organizational commitment was investigated with the use of four items $(44,45)$ (eg, "I am not willing to put myself out just to help the organization." "Even if the firm were not doing too well financially, I would be reluctant to change to another employer."). The participants were asked to respond to each item on a 4-point scale $(1=$ totally disagree, $4=$ totally agree). Item 1 was reverse-scored so that a high score indicated high organizational commitment.

Retirement age was asked in 2006 and was calculated from the question, "What year did you retire full-time?"

\section{Attrition analysis}

It was not possible to analyze the sample attrition in the first study phase, in 1996. When analyzing the attrition for the second phase of the study (in 1999), we compared the respondents $(\mathrm{N}=635)$ with the nonrespondents in the second survey $(\mathrm{N}=400)$. The results from the t-tests indicated that the respondents in 1999 did not differ statistically significantly from the nonrespondents at the baseline in 1996 in terms of age $[\mathrm{t}(1029)=0.545]$, managerial level [ $\mathrm{t}(1027)=0.537]$, supportive organizational climate $[\mathrm{t}(1029)=1.742]$, job control $[\mathrm{t}(1033)=0.550]$, job involvement $[\mathrm{t}(1030)=-$ 1.448], or organizational commitment [ $\mathrm{t}(1030)=-0.550]$. However, the respondents in 1999 had a higher level of work ability (mean 43.45) than the nonrespondents (mean 42.28) in 1996 [ $\mathrm{t}(1027)=4.397, \mathrm{P}<0.001]$. This difference may be explained by the omission of retired managers from the study sample at the time of the second measurement in 1999.

In 2006, the respondents $(\mathrm{N}=785)$ were older (mean 54.63 years) on the average than the nonrespondents $(\mathrm{N}=225$, mean 50.87 years $)$ [ $\mathrm{t}(1005)=-5.941, \mathrm{P}<0.001]$. The respondents in 2006 did not differ statistically significantly from the nonrespondents with respect to the following factors measured at the baseline of the study (in 1996): managerial level [ $\mathrm{t}(1003)=-0.586]$, supportive organizational climate $[\mathrm{t}(1004)=-0.624]$, job control $[\mathrm{t}(1008)=-0.489]$, job involvement $[\mathrm{t}(1005)=-0.076]$, organizational commitment $[\mathrm{t}(1005)=1.061]$, or work ability $[\mathrm{t}(1002)=-0.476]$. Thus the attrition analyses performed showed that the participants in the follow-up studies (in 1999 and 2006) were relatively representative of the persons who participated in the study in its first phase (in 1996).

\section{Statistical analyses}

We used group-based semiparametric mixture modeling $(28,29)$ for the estimation of the development trajectories for the managers' work ability over a 10-year follow-up period. By using this type of analysis, we were able (i) to identify distinct subgroups of persons following different development trajectories with respect to the characteristic in question, (ii) to estimate the proportion of the study population following each development trajectory, and (iii) to assign an individual to the trajectory group to which he or she most likely belonged. The trajectories could differ in terms of both the level of the characteristic in question and the shape of its development course. It was possible, for example, that a certain subgroup of persons showed an initially low level for a characteristic and then this characteristic linearly increased over time. Alternatively, it could be that a subgroup started with a high level for a characteristic and the level remained stable across time. When compared with a traditional cluster analysis, the mixture model had the advantage of being model-based and permitted the use of statistical criteria for deciding the number of clusters.

We used a censored normal option for the model estimation, and our selection of the optimal number of groups and trajectory shapes was guided by the Bayesian information criterion (BIC) $(27,28)$. As suggested by Nagin $(28,29)$, the model with the lowest BIC value 
was to be recommended. We also considered the sizes of the obtained groups and their interpretation in the model selection. The software we employed was an SAS-based procedure.

When compared with a traditional cluster analysis, the mixture model had the advantage of being a modelbased analysis that permitted the use of statistical criteria for deciding the number of latent groups.

The possible differences in the work ability trajectory groups regarding age were analyzed with the use of an analysis of variance (ANOVA), and for managerial level the chi-square test was used. An analysis of covariance (ANCOVA) was used to test the differences between the work ability groups with respect to work resources (ie, job control, organizational climate) and work attitudes (ie, work involvement, organizational commitment). In these analyses, age and management level were set as covariates. Finally, the mean differences in retirement age between the trajectory groups were investigated with the use of an ANOVA. These group comparisons were carried out using SPSS version 15.0 (SPSS Inc, Chicago, IL, USA).

\section{Results}

\section{Descriptive results}

The means, standard deviations, reliabilities (Cronbach's alpha), and the intercorrelations between the study variables are presented in table 1 . The test-retest correlations showed that the rank-order stability of work ability was relatively high across the measurement times $(\mathrm{r}=0.49-0.65)$. The work resources measured in 1996 were positively related to concurrent and subsequent work ability $(\mathrm{r}=0.15-0.23)$; the more supportive the organizational climate and the higher the job control, the higher the level of work ability reported by the participants. Organizational commitment correlated significantly with work ability in 1996 and 1999 (r=0.13-0.19), but no significant correlations were found between job involvement and work ability. Older managers reported higher levels of job involvement, organizational commitment, and job control and a lower level of work ability than the younger managers did. In addition, when compared with lower-level managers, upper-level managers reported that the organizational climate and job control were higher. They were also more committed to their job and organization, and their level of work ability was higher in the first two study phases than that of the other managers.

\section{Development trajectories of work ability}

The trajectory analysis involved 1033 participants (ie, persons who had a work ability index recorded at a minimum of one measurement point) since two persons had to be omitted from the analysis because they did not have a work ability index for any of the measurement points.

We selected the model with five trajectories on the basis of its BIC value and interpretability. This solution had lower BIC values than the two-, three- and fourgroup solutions. The BIC value of the six-trajectory solution was close to that of the five-group model, but the latter solution was supported by its group sizes and meaningful interpretation. According to the rule for maximum likelihood probability, persons in a given trajectory group should have a higher mean probability of assignment to that particular group than to the other groups. A value higher than 0.80 is generally assumed to imply a good model fit to the data (29). In our study, the mean assignment probabilities were rather high $(0.87$, $0.72,0.85,0.75$, and 0.91 for groups 1 to 5 , respectively) and indicated a satisfactory model fit.

Table 1. Pearson intercorrelations (Spearman for management level) between study variables ( $N=1033-413)$.

\begin{tabular}{|c|c|c|c|c|c|c|c|c|c|c|c|c|c|}
\hline \multirow[t]{2}{*}{ Variables } & \multicolumn{4}{|c|}{ Item } & \multirow{2}{*}{$\begin{array}{l}\text { Cronbach's } \\
\text { alpha }\end{array}$} & \multirow[t]{2}{*}{1} & \multirow[t]{2}{*}{2} & \multirow[t]{2}{*}{3} & \multirow[t]{2}{*}{4} & \multirow[t]{2}{*}{5} & \multirow[t]{2}{*}{6} & \multirow[t]{2}{*}{7} & \multirow[t]{2}{*}{8} \\
\hline & $\mathrm{N}$ & Range & Mean & SD & & & & & & & & & \\
\hline 1. Age in 1996 & & & 43.95 & 8.53 & & & & & & & & & \\
\hline 2. Management level ${ }^{\text {a }}$ & & & 2.07 & 0.80 & & $0.17^{b}$ & & & & & & & \\
\hline 3. Supportive organizational climate, 1996 & 4 & $1-5$ & 3.25 & 0.88 & 0.83 & 0.02 & $-0.14^{b}$ & & & & & & \\
\hline 4. Job control, 1996 & 4 & $1-5$ & 4.15 & 0.59 & 0.75 & 0.07 & $-0.35^{b}$ & 0.32 & & & & & \\
\hline 5. Job involvement, 1996 & 4 & $1-4$ & 2.75 & 0.53 & 0.72 & 0.15 & $-0.20^{b}$ & 0.12 & 0.21 & & & & \\
\hline 6. Organizational commitment, 1996 & 4 & $1-4$ & 3.01 & 0.52 & 0.60 & 0.16 & $-0.18^{b}$ & 0.33 & 0.34 & 0.50 & & & \\
\hline 7. Work ability in 1996 & 7 & $7-49$ & 42.92 & 4.33 & 0.70 & -0.25 & $-0.10^{b}$ & 0.23 & 0.23 & 0.04 & 0.19 & & \\
\hline 8. Work ability in 1999 & 7 & $7-49$ & 42.30 & 4.63 & 0.76 & -0.23 & $-0.10^{\mathrm{b}}$ & 0.19 & 0.23 & -0.04 & 0.13 & 0.65 & \\
\hline 9. Work ability in 2006 & 7 & $7-49$ & 42.21 & 5.26 & 0.81 & -0.17 & $-0.04 b$ & 0.15 & 0.17 & -0.06 & 0.05 & 0.49 & 0.50 \\
\hline
\end{tabular}

a 1 = upper level; 3 = lower level).

b Spearman correlation

$r=|0.07-0.09|, P<0.05 ; r=|0.10-0.12|, P<0.01 ; r \geq|0.13|, P<0.001$. 


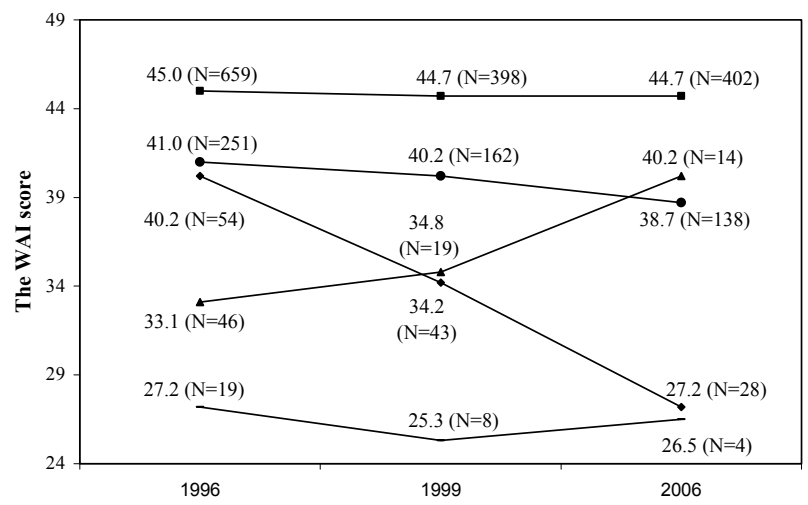

Table 2. Distribution of participants (\%) in the different managerial levels within each work ability trajectory at the study baseline in $1996(\mathrm{~N}=1033)$.

\begin{tabular}{|c|c|c|c|c|c|c|}
\hline $\begin{array}{l}\text { Managerial } \\
\text { levels }\end{array}$ & $\begin{array}{l}\text { 1. Work } \\
\text { ability } \\
\text { consis- } \\
\text { tently } \\
\text { excellent } \\
(\mathrm{N}=662)\end{array}$ & $\begin{array}{l}\text { 2. Work } \\
\text { ability } \\
\text { good } \\
\text { (declin- } \\
\text { ing) } \\
(\mathrm{N}=252)\end{array}$ & $\begin{array}{l}\text { 3. Work } \\
\text { ability } \\
\text { declined } \\
\text { from } \\
\text { good to } \\
\text { poor } \\
(\mathrm{N}=54)\end{array}$ & $\begin{array}{l}\text { 4. Work } \\
\text { ability } \\
\text { improv- } \\
\text { ed from } \\
\text { mode- } \\
\text { rate to } \\
\text { good } \\
(\mathrm{N}=46)\end{array}$ & $\begin{array}{l}\text { 5. Work } \\
\text { ability } \\
\text { consis- } \\
\text { tently } \\
\text { poor } \\
(\mathrm{N}=19) \\
\end{array}$ & $\begin{array}{ll}\text { Total } & \chi^{2-} \\
& \text { test }\end{array}$ \\
\hline Upper level & $70.7^{\mathrm{a}}$ & 23.2 & $3.1^{b}$ & 2.7 & $0.3^{b}$ & $10022.39^{c}$ \\
\hline Middle level & 65.2 & 23.3 & 6.3 & 3.6 & 1.6 & 100 \\
\hline Lower level & $58.0^{\mathrm{b}}$ & 26.3 & 5.9 & $6.8^{a}$ & $3.0^{\mathrm{a}}$ & 100 \\
\hline
\end{tabular}

a Typical.

${ }^{\mathrm{b}}$ Atypical, adjusted residual $>|2|$.

c $\mathrm{P}<0.01$.

In the five-group model (figure 1), based on the whole available sample of 1033 participants, the first group $(\mathrm{N}=662,64 \%)$ consisted of the participants whose work ability remained excellent during the follow-up (henceforth labeled as "work ability consistently excellent"). The second group ( $\mathrm{N}=252,24 \%)$ was characterized by a good level of work ability, although the work ability declined linearly to a statistically significant level, and was denoted as "work ability good but declining". The third group, which was named "work ability declined from good to poor," consisted of 54 participants (5\%). This group was characterized by a good level of work ability in 1996 and 1999 but by a linearly decreased level to poor by 2006 . The decline in work ability was statistically significant. An improvement in work ability was observed in the fourth group during the follow-up period. This group's work ability was moderate at the baseline, but it had improved linearly and significantly to a good level by the last measurement. This group included 46 participants (5\%) and was labeled "work ability improved from moderate to good." The smallest development trajectory, with only 19 participants (2\%), was characterized by poor work ability at each of the three measurement points. Therefore, this group was labeled as "work ability consistently poor."

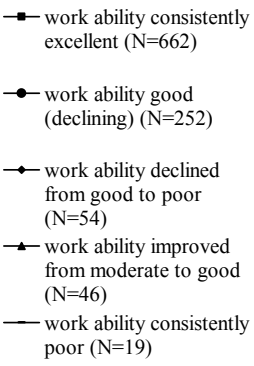

Figure 1. Development trajectories of work ability. The figure depicts the trajectories with sum scores for work ability and the number of participants in parentheses at each measuring point.

\section{Differences in the work ability trajectories}

Age. The results from the ANOVA indicated that the trajectory groups differed from each other according to age $[\mathrm{F}(4,1024)=12.11, \mathrm{P}<0.001]$. The participants who belonged to the group "work ability consistently excellent" were younger in the first study phase in 1996 [mean 42.7 (SD 8.5) years] than those who belonged to the groups "work ability good but declining" [mean 45.8 (SD 8.2) years], "work ability declined from good to poor" [mean 47.2 (SD 6.6) years], "work ability improved from moderate to good" [mean $46.6(\mathrm{SD}=9.4)$ years], or "work ability consistently poor" [mean 49.4 (SD 8.5) years].

Management level. As can be seen in table 2, there were significant differences among the work ability trajectories within each managerial level. Upper-level managers were more often in the group of "work ability consistently excellent", and they were underrepresented in the groups of "work ability declined from good to poor" and "work ability consistently poor". Lower-level managers, in turn, were underrepresented in the group of "work ability consistently excellent" and overrepresented in the groups of "work ability increased from moderate to good" and "work ability consistently poor". No differences were detected in terms of the trajectories among the middle-level managers.

Work resources. The results of the ANCOVA showed that the highest level of supportive organizational climate and job control were found for those whose work ability was consistently excellent (table 3 ). The lowest level of supportive organizational climate was obtained for those whose work ability improved from moderate to good. Those whose work ability was consistently poor reported the lowest level of job control at the baseline of the study.

Work attitudes. The results of the ANCOVA further indicated that the work ability groups did not differ from each other in job involvement (table 3). However, 
Table 3. Estimated mean scores of the work characteristics and work attitudes at the baseline of the study (antecedent variables) in 1996 in each work ability trajectory (analysis of covariance; age and managerial level as covariates).

\begin{tabular}{|c|c|c|c|c|c|c|c|c|c|c|c|c|}
\hline \multirow[t]{2}{*}{ Antecedent variable (range) } & \multicolumn{2}{|c|}{$\begin{array}{l}\text { 1. Work ability } \\
\text { consistently } \\
\text { excellent } \\
\text { (N=662) }\end{array}$} & \multicolumn{2}{|c|}{$\begin{array}{l}\text { 2. Work ability } \\
\text { good } \\
\text { (declining) } \\
(\mathrm{N}=252)\end{array}$} & \multicolumn{2}{|c|}{$\begin{array}{l}\text { 3. Work ability } \\
\text { declined from } \\
\text { good to poor } \\
(N=54)\end{array}$} & \multicolumn{2}{|c|}{$\begin{array}{l}\text { 4. Work ability } \\
\text { improved from } \\
\text { moderate to good } \\
(\mathrm{N}=46)\end{array}$} & \multicolumn{2}{|c|}{$\begin{array}{l}\text { 5. Work ability } \\
\text { consistently } \\
\text { poor } \\
(\mathrm{N}=19)\end{array}$} & \multirow[t]{2}{*}{ F-test } & \multirow[t]{2}{*}{$\begin{array}{l}\text { Pairwise } \\
\text { comparison }^{\text {a }}\end{array}$} \\
\hline & Mean & SD & Mean & SD & Mean & SD & Mean & SD & Mean & SD & & \\
\hline Supportive organizational climate (1-5) & 3.37 & 0.03 & 3.11 & 0.06 & 2.97 & 0.12 & 2.72 & 0.13 & 2.85 & 0.20 & $10.86^{b}$ & $1>2,3,4 ; 2>4$ \\
\hline Job control $(1-5)$ & 4.25 & 0.21 & 3.98 & 0.03 & 4.07 & 0.07 & 3.92 & 0.08 & 3.86 & 0.13 & $14.12^{b}$ & $1>2,4,5$ \\
\hline Job involvement (1-4) & 2.74 & 0.02 & 2.78 & 0.03 & 2.79 & 0.07 & 2.63 & 0.08 & 2.59 & 0.12 & $1.43^{c}$ & \\
\hline Organizational commitment (1-4) & 3.07 & 0.02 & 2.94 & 0.03 & 2.92 & 0.07 & 2.73 & 0.07 & 2.71 & 0.12 & $8.47^{b}$ & $1>2,4,5$ \\
\hline
\end{tabular}

Table 4. Description of the attrition in five work ability trajectories at the third measurement time of the study (in 2006).

\begin{tabular}{|c|c|c|c|c|c|c|c|c|c|c|}
\hline \multirow[t]{2}{*}{ Work ability trajectories } & \multicolumn{2}{|c|}{ Retirees } & \multicolumn{2}{|c|}{ Deaths } & \multicolumn{2}{|c|}{ Not contactable } & \multicolumn{2}{|c|}{ Unemployed } & \multicolumn{2}{|c|}{$\begin{array}{l}\text { Unexplained } \\
\text { attrition }\end{array}$} \\
\hline & $\mathrm{N}$ & $\%$ & N & $\%$ & $\mathrm{~N}$ & $\%$ & $\mathrm{~N}$ & $\%$ & $\mathrm{~N}$ & $\%$ \\
\hline 1. Work ability consistently excellent & 67 & 10 & 12 & 2 & $7^{\mathrm{a}}$ & 1 & 21 & 3 & 153 & 23 \\
\hline 2. Work ability good (declining) & 48 & 19 & 8 & 3 & $2^{\mathrm{a}}$ & 1 & 13 & 5 & 43 & 17 \\
\hline 3. Work ability declined from good to poor & 13 & 24 & 2 & 4 & - & & 4 & 7 & 7 & 13 \\
\hline 4. Work ability improved from moderate to good & 16 & 35 & 2 & 4 & $1^{\mathrm{a}}$ & 2 & 3 & 7 & 10 & 22 \\
\hline 5. Work ability consistently poor & 10 & 53 & 1 & 5 & $1^{b}$ & 5 & - & & 3 & 16 \\
\hline
\end{tabular}

a Withheld address.

${ }^{b}$ Serious illness.

significant differences were found in organizational commitment in that the persons in the "work ability consistently excellent" group were the most committed and those in the "work ability consistently poor" group were the least committed to their organization.

\section{Retirement age with respect to the work ability trajec- tories}

As can be seen from figure 1, the number of participants in each of the trajectories decreased during the study, particularly at the last measurement point (with the exception of the group "work ability consistently excellent"). Therefore, we investigated the reasons (ie, the number of unemployed, deceased, or not contactable due to a withheld address, and the unexplained attrition) behind these missing cases at the last measurement point in 2006. The description of the missing cases in each trajectory is summarized in table 4 . The percentage proportions of retirees increased from the first trajectory group (ie, "work ability consistently excellent") to the fifth group (ie, "work ability consistently poor").

According to the results of the ANOVA, there were significant differences in the retirement ages between the trajectories $[\mathrm{F}(4,147)=7.352, \mathrm{P}<0.001]$. Bonferroni posthoc comparisons indicated that the retirement age was significantly lower in the "work ability consistently poor" group [mean 55.4 (SD 5.54) years] than in the groups of "work ability consistently excellent" [mean 61.3 (SD 3.07) years], "work ability good but declining" [mean 61.3 (SD 3.64) years], and "work ability improved from moderate to good" [mean 60.8 (SD 2.15) years]. However, retirement age in the poor work ability group did not differ from retirement age [mean 59.1 (SD 4.13) years] in the group "work ability declined from good to poor".

\section{Discussion}

In the present study, we investigated the change in work ability over time from a person-oriented perspective (23-26) by means of a trajectory analysis $(28,29)$. Thus our method of analysis of work ability differed from that of previous work ability research in which mean changes in the work ability scores have been studied either for the whole study sample or for predefined subgroups. Latent groups-differing in size and type of change in work ability - were revealed by our method of analysis for the first time. These kinds of groups have remained 
undetected because the traditional variable-oriented analysis has dominated work ability research.

With the present trajectory analysis used for Finnish managers, a total of five latent groups of work ability development were identified over a follow-up period of 10 years. As expected, most of the managers were located within the favorable work ability trajectories. The work ability remained excellent among $64 \%$ of the managers during the follow-up period, and the proportion increased to $88 \%$ when managers with good (although decreasing) work ability were included. In light of previous work ability and occupational health studies, the managers' favorable trend for work ability was expected. Managerial work is rather more mentally than physically demanding (31), a fact that has been found to be a significant protective factor for good work ability $(5,21)$. Managers' work also includes many other protective factors, such as high job control $(31,42)$. The perceptions of high job control were confirmed also in our study, especially among the managers in the uppermanagement levels.

As expected, managers' younger age, higher management position, high job control, supportive organizational climate, and high organizational commitment at the baseline of the study in 1996 were related to the favorable changes that occurred in the managers' work ability. These factors accurately described the most favorable group "work ability consistently excellent," but also the group "work ability good but declining." Also in line with our expectations, the number of retired managers was lowest in these favorable groups at the end of the follow-up period (in 2006), and, in addition, the mean age of retirement was highest in these groups.

Despite the novel methodological approach chosen for our study, our observations of the baseline factors affecting the work ability trajectories were congruent with previous research findings based on variableoriented methods. The finding regarding a higher managerial level as an antecedent factor for favorable work ability development is in line with previous research findings. Upper-level managers have reported better health and well-being (eg, lower stress symptoms, higher satisfaction) than managers in lower-level positions $(42,44,46,47)$. The observed association between higher age and a decrease in work ability or health indicators has also been found for many other occupational groups $(5,18-20,21,48-50)$. However, it must be noted that the age link with the work ability scores is not unambiguous. The recent research findings for 19507 Dutch construction workers have indicated that the role of age in lowered work ability scores is rather limited after work-related risk factors have been adjusted for (21).

Furthermore, the central role of work resources in facilitating changes in managers' work ability is in accord with the hypotheses of Karasek's job demand-control model (37) and its expanded job demand-control-support model (38). High job control promotes active learning, motivation, and self-development at work and inhibits job strain and stress-related symptoms and diseases. A supportive organizational climate is also essential to managerial work and work ability. When a manager receives support and acceptance from other members of the organization, for example, in decision making, it is advantageous for his or her well-being and work ability. In addition, the managers' high level of organizational commitment played a role in the favorable development of work ability - a finding that also met our hypothetical assumption (39). It could be that, for managers who are committed to their organization, their work offers better resources, which in turn facilitates favorable trajectories for work ability. Our findings also point in this direction as work resources were linked to organizational commitment.

An important observation of our study was the association between the development of managers' work ability and with their retirement age. Although the low number of retired managers in the smallest work ability trajectories restricted the possibility to draw any definite conclusions, the mean differences in retirement age between the trajectories were nevertheless notable. The mean retirement age was the highest for the managers in the most favorable work ability groups (61.3 years), whereas it was 5.9 years lower (ie, 55.4 years) in the least favorable work ability group (ie, "work ability consistently poor"). Thus our observations were in line with those of previous prospective studies on work ability, in which a low work ability index was found to predict early retirement $(17,18)$.

Our study revealed unique knowledge about the direction in which the work ability of managers develops over the long term. These directions were characterized by work ability remaining stable $(66 \%)$ (ie, groups "work ability excellent" and "work ability consistently poor"), linearly decreasing (30\%) (ie, groups "work ability good but declining" and "work ability declined from good to poor"), or linearly increasing (4\%) (ie, group "work ability improved from moderate to good"). No trajectories were identified for which the development in work ability was nonlinear. Over half of the investigated managers were able to resist a decrease in their work ability. The work ability of a relatively high number of managers showed a decreasing trend, however. The decline in work ability can at least partially be explained by the long follow-up period of our study. The investigated managers were 10 years older at the end of the follow-up than at the beginning of the study. Accordingly, lower levels of work ability have previously been found to be associated with increasing age and an increase in the occurrence of physical illnesses $(45,49)$. 
The small group of managers with improving work ability was perhaps the most interesting group detected in our study. The managers in this group had the lowest rating for their organizational climate at the baseline of the study. Compared with the group with the most favorable development in work ability, this group scored significantly lower also in job control and organizational commitment. Due to the prospective nature of our study, however, it remains unclear whether the increase in work resources or work attitudes could have explained this improvement in work ability. Changes in the managers' work or careers could have played a role; for example, job insecurity could have been experienced at the beginning of the study since it incorporated the years just after the severe economic recession in Finland in the early 1990s. These explanations remain, unfortunately, only speculative at this time.

A number of limitations and areas for future research should be noted, including the response rates across the measurement times of our study, the possibility of reverse causality between investigated antecedent baseline factors and work ability trajectories, implications of our findings for occupations that were not managerial (eg, blue-collar workers), and the difficulty of attaining a more in-depth understanding of the development course of the different dimensions of the work ability index.

Unfortunately, we were only able to obtain a $64 \%$ response rate in the initial survey (in 1996), and this rate is less than ideal for a population-profiling study (51). Consequently, it is unknown whether the nonrespondents differed from the respondents with regard to background factors and work ability at the beginning of the study. The critical question is, for example, whether they were too stressed to participate in the survey. In later data collections (in 1999 and 2006), a part of the attrition could be analyzed. The analysis showed that the participants in the follow-up represented the persons who participated in the study in the first study phase relatively well (1996). However, it is important to remember that several factors not explored in our study may have had the ability to alter the present findings concerning work ability. For example, the quality of one's family life or social relationships outside of work are assumed to be relevant with respect to a person's work ability $(4,5,17)$.

Another drawback is the possible reverse causality between the factors assessed at the beginning of the study (managerial level, work resources, work attitudes) and the changes in work ability over time. Consequently, the levels of these factors could have been partially determined by the managers' work ability scores as well. For example, managers' good work ability might sustain their organizational commitment. This dual role has also been noted with the use of the recent job demand-resources model (39), which assumes a reciprocal link between ill-health and commitment. A further limitation of our study was the lack of an opportunity to assess the possible changes in the antecedent (baseline) factors of the work ability trajectories. An effective statistical test of these changes was not possible due to the small number of persons in three trajectories, particularly at the third measurement time.

Our study also focused on a strongly male-dominated sample of managers, and this restriction does not allow for direct generalizations of the results to female managers or other occupational groups (eg, blue-collar workers). It is probable as well that, in physically demanding occupations, the development trajectories of work ability are not as favorable as they were for the managers included in our study. Thus future research should study the developmental trajectories of work ability in other occupations as well in order to get a more complete picture of the changes that occur in work ability over time.

Finally, because the present trajectory analyses were based on the total score of the work ability index, we cannot say anything about the course of development for the different dimensions included in the index. This knowledge would help researchers better understand the role of these dimensions within the total score. With respect to a person-oriented perspective regarding this issue, it would be important to compare, for example, the development trajectories of psychological resources (one aspect of the work ability index) with indicators related closely to physical health (eg, the number of diseases diagnosed by a physician in the work ability index). These data would add to our understanding of which dimensions in the work ability index are the most resistant to aging.

The contributions of our study extend beyond the novel methodological approach and the long follow-up period of the study. The findings also enable practical implications to be assessed on the basis of the results. Our findings suggest that organizations and occupational health care should pay particular attention to the work conditions of lower-level managers, who were found to be at greater risk of unfavorable development with respect to their work ability and, consequently, early retirement. One of the key issues would be to improve their job control in organizations. In addition, preventing a decline in aging managers' work ability requires special attention. Because of the high psychological demands of managerial work (eg, profit responsibility, interpersonal demands, demands caused by changing work environments), it could be useful, for example, to design specific interventions for aging managers in order for them to meet their work demands better. Finally, our results suggest that it would be worthwhile for organizations to foster managers' organizational commitment, which has been found to 
promote the favorable development of work ability in the long term.

\section{Acknowledgments}

The FINNMA-10 study was funded by the Finnish Work Environment Fund (project 105363). Katja Kokko was funded by a research grant (number 118316) from the Academy of Finland.

\section{References}

1. Kalwij A, Vermeulen, F. Health and labour force participation of older people in Europe: what do objective health indicators add to the analysis? Health Econ. 2008;7:619-38.

2. Huuhtanen P, Tuomi K. Työ ja työkyky vakavien eläkeajatusten ennustajina: seurantatutkimus kunta-alalla 1981-92 sekä eläkeajatusten toteutuminen 1997 [Work and work ability as predictors of retirement thoughts: a follow-up study in the municipal sector in Finland in 1981-97 and realization of the retirement thoughts]. Työ ja Ihminen. 2006;20(1):22-41.

3. Ilmarinen J. Promotion of work ability during aging. In: Kumahiro M, editor. Aging and work. London: Taylor \& Francis; 2003. p 21-35.

4. Ilmarinen J, Tuomi K, Seitsamo J. New dimensions of work ability. Int Congr Ser. 2005;1280:3-7.

5. Ruoppila I, Huuhtanen P, Seitsamo J, Ilmarinen J. Age-related changes of the work ability construct and its relation to cognitive functioning in the older worker: a 16-year follow-up study. Jyväskylä: University of Jyväskylä; 2008. Jyväskylä studies in education, psychology and social research, no 336.

6. Ilmarinen J, Tuomi K, Klockars, M. Changes in the work ability of active employees over an 11-year period. Scand J Work Environ Health. 1997;23 suppl 1:49-57.

7. Ilmarinen J, guest editor. The aging worker. Scand J Work Environ Health 1991;17 suppl 1:1-141.

8. Ilmarinen J, Tuomi K, Eskelinen L, Nygård C-H, Huuhtanen P, Klockars M. Background and objectives of the Finnish research project on aging workers in municipal occupations. Scand J Work Environ Health. 1991;17 suppl 1:7-11.

9. Tuomi K, Ilmarinen J, Seitsamo J, Huuhtanen P, Martikainen R, Nygård C-H, et al. Summary of the Finnish research project (1981-1992) to promote the health and work ability of aging workers. Scand J Work Environ Health. 1997;23 suppl 1:66-71.

10. Tuomi K, (editor). Eleven-year follow-up of aging workers. Scand J Work Environ Health. 1997; 23 suppl 1:1-71.

11. Ilmarinen J. The work ability index (WAI). Occup Med. 2007;57:160.

12. Gosta G, Goedhard WJA, Ilmarinen J, editors. Assessment and promotion of work ability, health and well-being of ageing workers. Int Congr Ser. 2005;1280:1-435.

13. Tuomi K, Ilmarinen J, Jahkola A, Katajarinne L, Tulkki A. Work ability index. 2nd ed. Helsinki: Finnish Institute of Occupational Health; 1997.

14. Tuomi K, Ilmarinen J, Jahkola A, Katajarinne L, Tulkki A. Work ability index. 2nd ed. Helsinki: Finnish Institute of Occupational Health; 2006.
15. Kujala V, Tammelin T, Remes J, Vammavaara E, Ek E, Laitinen J. Work ability index of young employees and their sickness absence during the following year. Scand J Work Environ Health. 2006;32(1):75-84.

16. Nygård C-H, Arola $\mathrm{H}$, Siukola A, Savinainen M, Luukkaala $\mathrm{T}$, Taskinen $\mathrm{H}$, et al. Perceived work ability and certified sickness absence among workers in food industry. Int Congr Ser. 2005;1280:296-300.

17. Ilmarinen J, Tuomi K. Past, present and future of work ability. Helsinki: Finnish Institute of Occupational Health; 2004. People and work research reports, no 65, p 1-25.

18. Liira J, Matikainen E, Leino-Arjas P, Malmivaara A, Mutanen $\mathrm{P}$, Rytkönen $\mathrm{H}$, et al. Work ability of middle-aged Finnish construction workers-a follow-up study in 1991-1995. Int J Ind Ergon. 2000;25:477-81.

19. Rasku A, Ruoppila I, Feldt T. Esimiesten työkyky: yksilölliset ja työhön liittyvät tekijät yli 55-vuotiailla esimiehillä [Managers work ability: individual and work-related factors among managers over 55 years]. Gerontologia. 1999;13:13-21.

20. Pohjonen T. Perceived work ability of home care workers in relation to individuals and work-related factors in different age groups. Occup Med. 2001;51:209-17.

21. Alavinia SM, van Duivenbooden J, Burdorf A. Influence of work-related factors and individual characteristics on work ability among Dutch construction workers. Scand J Work Environ Health. 2007;33(5):351-7.

22. van den Berg TIJ, Alavinia SM, Bredt FJ, Lindeboom D, Elders LAM, Burdorf A. The influence of psychosocial factors at work and life style on health and work ability among professional workers. Int Arch Occup Environ Health. 2008;81:1029-36.

23. Magnusson D: The logic and implications of a person-oriented approach. In: Cairns RB, Bergman LR, Kagan J, editors. Methods and models for studying the individual. Thousands Oaks (CA): Sage; 1998. p 33-64.

24. Bergman LR, Trost $K$. The person-oriented versus the variableoriented approach: are they complementary, opposities, or exploring different worlds? Merrill-Palmer Q. 2006;52:601-32.

25. von Eye A, Bogat GA. Person-oriented and variable-oriented research: concepts, results, and development. Merrill Palmer Q. 2006;52:390-419.

26. Laursen B, Hoff E. Person-centered and variable-centered approaches to longitudinal data. Merrill Palmer Q. 2006;52:37789.

27. Magnusson D. On the individual: a person-oriented approach to developmental research. Eur Psychol. 1999;4:205-18.

28. Nagin DS. Analyzing developmental trajectories: a semi-parametric, group-based approach. Psychol Methods. 1999;4:13977.

29. Nagin DS. Group-based modeling of development. Boston (MA): Harvard University Press; 2005.

30. Kokko K. Kehityspolkuanalyysi tilastollisena menetelmänä: soveltajan näkökulma [Trajectory analysis as a statistical tool from applicant's approach]. Psykologia. 2004;39:424-33.

31. Tarvainen T, Kinnunen U, Feldt T, Mauno S, Mäkikangas A. Kuormitus- ja voimavaratekijät suomalaisten johtajien työssä [Demands and resources in managerial work]. Työ ja ihminen. 2005;9:440-56.

32. Mäkikangas A, Feldt T, Kinnunen U. Warr's scale of job-related affective well-being: a longitudinal examination of its structure and relationships with work characteristics. Work Stress. 2007;21:197-219.

33. Aittomäki A, Lahelma E, Roos E. Work conditions and socioeconomics inequalities in work ability. Scand J Work Environ Health. 2003;29(2):159-65. 
34. Sluiter J K. High-demand jobs: age-related diversity in work ability? Appl Ergon. 2006:37;429-40.

35. Torgen M. Experiences of WAI in a random sample of the Swedish working population. Int Congr Ser. 2005;1280:328332.

36. Tuomi K, Eskelinen L, Toikkanen J, Jarvinen E, Ilmarinen J, Klockars M. Work load and individual factors affecting work ability among aging municipal employees. Scand J Work Environ Health. 1991:17 suppl 1;128-34.

37. Karasek RA. Job demands, job decision latitude, and mental strain: implications for job redesign. Admin Sci Q. 1979;24:285-308.

38. Karasek RA, Theorell T. Healthy work: stress, productivity, and the reconstruction of working life. New York (NY): Basic Books; 1990.

39. Bakker AB, Demerouti E. The job demands resources model: state of the art. J Man Psychol. 2007;22:309-328.

40. Feldt T, Mäkikangas A, Hyvönen K, Kinnunen U, Kokko K. Esimiesten työkyvyn kehityspolut vuosina 1996-2006 [The developmental trajectories of managers' work ability and their antecedents in a 10-year follow-up study from 1996 to 2006]. Työ ja ihminen. 2006;20:303-21.

41. Hyvönen K, Mäkikangas A, Kinnunen U, Ruoppila I, Feldt T. Managers' work and occupational well-being between the years of 1996 and 2006: longitudinal evidence from the FINNMA-10 study. Jyväskylä: University of Jyväskylä; 2008. Reports from the Department of Psychology, no 351.

42. Feldt T, Kivimäki M, Rantala A, Tolvanen A. Sense of coherence and work characteristics: a cross-lagged structural equation model among managers. J Occup Organ Psychol. 2004;77:323-42.

43. Kanungo RN. Measurement of job and work involvement. J
Appl Psychol. 1982;67:341-9.

44. Mauno S, Kinnunen U. The stability of job and family involvement: applying the multi-wave, multi-variable technique to longitudinal data. Work Stress. 2000;14:51-64.

45. Cook J, Wall TD. New work attitude measures of trust, organizational commitment and personal need non-fulfillment. J Occup Psychol. 1980:53;39-52.

46. Feldt T, Mäkikangas, Kinnunen U. Onko esimiesten työsitoutuneisuus heidän terveytensä voimavara vai riskitekijä? [Is managers' work involvement a risk or protective factor for their health?]. Työ ja ihminen. 2003;4:292-303.

47. Kinnunen U, Feldt T, Mäkikangas A. Testing the effort-reward imbalance model among Finnish managers: the role of perceived organizational support. J Occup Health Psychol. 2008;13:114-27.

48. Seitsamo J, Klockars M. Aging and changes in health. Scand J Work Environ Health. 1997;23 suppl 1:27-35.

49. Seitsamo J. Retirement transition and well-being: a 16-year longitudinal study. Helsinki: Finnish Institute of Occupational Health; 2007. People and Work Research Reports, no 76.

50. Helakorpi S, Patja K, Prättälä R, Aro AR, Uutela A. Suomalaisen aikuisväestön terveyskäyttäytyminen ja terveys, kevät 2003 [Health behavior and health among Finnish adult population, Spring 2003]. Helsinki: National Public Health Institute; 2003. Publications of the National Public Health Institute, no B17.

51. Barr CD, Spitzmuller C, Stuebing KK. Too stressed out to participate?: examining the relation between stressors and survey response behavior. J Occup Health Psychol. 2008;13:232-43.

Received for publication: 26 March 2008 